\title{
ALKALOIDS OF Verbascum songoricum
}

R. Ziyaev, A. Abdusamatov,

UDC $547.944 / 945$

and S. Yu. Yunusov

We have investigated $\underline{\mathrm{V}}$. songoricum Shrenk, family Scrophulariaceae collected in the village of Chimgan, Tashkent oblast, in the early vegetation periods, each organ being collected separately (Table 1).

From the leaves of $\mathrm{V}$. songoricum, chloroform extracted $0.07 \%$ of combined ethereal and $0.9 \%$ of combined chloroformic alkaloids. The ethereal fraction of the combined alkaloids was treated with petroleum ether. The TLC of this extract in the benzene-ethanol (4:1) system gave two spots with $R_{f} 0.42$ and 0.79 . By separation on a column of silica gel [benzene-ethanol (98:2)] we obtained a liquid base $\mathrm{C}_{10} \mathrm{H}_{\mathfrak{u}} \mathrm{N}_{2}$ with $\mathrm{R}_{f}$ $0.42,[\alpha]_{D}^{28}-76^{\circ}$ (c 0.3 ; chloroform), mol. wt. 162 (mass spectrum). The melting point of the picrate was $203-205^{\circ} \mathrm{C}$ (water).

The UV spectrum of the base had a maximum at $\lambda_{\max } 262 \mathrm{~nm}(\log \varepsilon 3.18)$, which is characteristic for alkaloids of the pyridine type. The IR spectrum exhibited absorption bands at $\left(\mathrm{cm}^{-1}\right) 3500-3200(>\mathrm{N}-\mathrm{H})$, 2980-2920 $\left(-\mathrm{CH}_{2} \rightarrow, 1600\right.$ (pyridine ring), 1060, and 720 。 $42 \mathrm{~m} / \mathrm{e}$.

The mass spectrum showed the following ionic peaks: $\mathrm{M}^{+} 162,161,133,119,105,84(100 \%), 56$ and

The results of a comparison of physicochemical properties and also of the UV, IR, and mass spectra of the base with literature data [1-2] showed that the alkaloid was anabasine.

The combined chloroformic alkaloids were separated according to their basicities into 10 fractions. On treatment with acetone, fraction 1 yielded a base with $\mathrm{mp} 218-220^{\circ} \mathrm{C}$, which proved to be identical with plantagonine [3]. Fractions $2-4$, on treatment with acetone, yielded substances with $\mathrm{mp} 195-196^{\circ} \mathrm{C}$ and $80-$ $82^{\circ} \mathrm{C}$, the latter being identified as acetamide.

Thus, we have isolated anabasine, plantagonine, and acetamide, and a base with $\mathrm{mp} 195-196^{\circ} \mathrm{C}$. This is the first time that anabasine has been isolated from the family Scrophulariaceae.

TABLE 1

\begin{tabular}{|c|c|c|c|c|c|}
\hline \multirow{2}{*}{$\begin{array}{l}\text { Date of } \\
\text { collection }\end{array}$} & Fruit & Buds & Leaves & Stems & Roots \\
\hline & \multicolumn{5}{|c|}{ combined alkaloid, \%of the wt. of the dry plant } \\
\hline $\begin{array}{l}\text { Sept. 10, } 1968 \\
\text { May 20, } 1970\end{array}$ & 0.12 & $0, \overline{23}$ & $\begin{array}{l}0,095 \\
0,16\end{array}$ & $\begin{array}{l}0,07 \\
0,086\end{array}$ & $\begin{array}{l}0,065 \\
0,076\end{array}$ \\
\hline
\end{tabular}

\section{LITERATURE CITED}

1. A. P. Orekhov, The Chemistry of the Alkaloids of Plants of the USSR. [in Russian], Moscow (1965), p. 37.

2. H. Budzikiewicz, C. Djerassi, and D. Williams, Interpretation of Mass Spectra of Organic Compounds, Holden-Day, San Francisco (1964).

3. Kh. Ubaev, P. Kh. Yuldashev, and S. Yu. Yunusov, Uzb。Khim, Zh., 1963, No. 3, 33.

Institute of the Chemistry of Plant Substances, Academy of Sciences of the Uzbek SSR. Translated from Khimiya Prirodnykh Soedinenil, No. 6, pp.853-854, November-December, 1971. Original article submitted July 13, 1971.

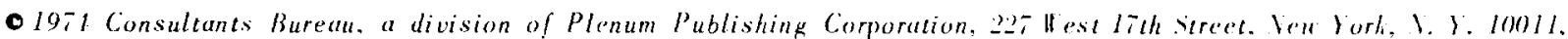
Lo part of this publication may be reproduced, stored in a retrievel system. or transmitted, in any form or by amy means, electronic, mechanical, photocopying. microfilming, recording or athereise, without uritten permission of the publisher. i copy of this article is available from the publisher for $\$ 1.5,00$. 